THE effect of L-carnitine and some of its acyl derivatives on serum TNF production and lethality in a murine experimental endotoxin shock model was investigated. In some instances, serum IL-6 production was also evaluated. In this experimental model, C57BL/6 mice received $30 \mathrm{mg} / \mathrm{kg}$ LPS (E. coli 055:B5) injected intraperitoneally, while L-carnitine and its derivatives were administered according to different schedules. Serum levels of TNF and IL-6 were evaluated $1 \mathrm{~h}$ following LPS injection. The treated animals were also monitored daily for differences in body temperature, feeding, and survival for $\mathbf{1 0}$ days after LPS injection. Although some derivatives were able to significantly affect TNF production, the marked decrease in serum TNF levels of LPS-treated mice was not paralleled by a substantial increase in survival.

Key words: Carnitines, Endotoxaemia, Endotoxin shock, Hypothermia, IL-6, LPS, Mice, Septic shock, TNF

\section{LPS-induced serum TNF production and lethality in mice: effect of L-carnitine and some acyl-derivatives}

\author{
Vito Ruggiero, Claudio M. D'Urso, Claudio \\ Albertoni, Silvia Campo, Piero Foresta ${ }^{\mathrm{CA}}$ \\ and Edoardo Arrigoni Martelli
}

Sigma Tau Ind. Farm., Riun. SpA, Research and Development, Department of Microbiology and Immunology, Via Pontina Km. 30, 400, 00040 Pomezia, Italy

${ }^{\mathrm{CA}}$ Corresponding Author

\section{Introduction}

Septic shock is a clinical syndrome associated with a high lethality rate, and characterized by various haemodynamic and immuno-biochemical alterations. ${ }^{1}$ This disease is primarily caused by Gram-negative bacteria, but it may also be consequent to infections by some Gram-positive bacteria, fungi, and probably parasites and viruses. ${ }^{2}$ The pathophysiological effects caused by Gramnegative bacteria have been ascribed to lipopolysaccharide (LPS) a component of the bacterial outer membrane, which has also been termed endotoxin because of its toxic effects. ${ }^{3}$ LPS causes septic shock by interacting with various components of the host's immune system, and primarily with macrophages, which in turn release several endogenous mediators that are themselves the ultimate effectors of the disease. ${ }^{4-6}$ Recently, the systemic release of large amounts of various cytokines has been associated with fatal outcome in human septic shock. ${ }^{7,8}$

TNF is one of the cytokines considered to play a pivotal role as a mediator of the host's response to LPS. ${ }^{9}$ Therefore, blocking or antagonizing TNF in sepsis may have therapeutic potential. Furthermore, making TNF a target for intervention, rather than LPS, may be more advantageous in that TNF has also been found to be involved in the pathogenesis of shock due to Gram-positive bacteria. ${ }^{10,11}$ Among the drugs used in giving metabolic support to septic patients, L-carnitine has been found to be a fairly good candidate to ameliorate the host's metabolic response to septic processes. ${ }^{12-14}$

L-Carnitine is a drug that is not only essential for the mitochondrial oxidation of long-chain fatty acids, but also for intercompartmental shuttling of energy substrates as well as elimination of toxic metabolites, and modulation of the free $\mathrm{CoA} / \mathrm{Acyl}$ CoA ratio. ${ }^{15}$ Although the information concerning the effects of carnitine on cells of the immune system is still scanty, a report showed that L-carnitine effectively inhibited chemiluminescence in PMA-stimulated human PMN leukocytes. ${ }^{16}$ This is of some interest in the light of the findings that both chemiluminescence as well as TNF production are phenomena negatively regulated by cyclic nucleotides. ${ }^{17,18}$ In this report the authors investigated the effect of L-carnitine and some of its acyl derivatives on endotoxin-induced serum TNF production, lethality, and some physiological responses (feeding and body temperature) in a murine experimental endotoxin shock model.

Experimental endotoxaemia has become a valuable experimental model for septicaemia in laboratory animals. Although this model does not completely reproduce all the features of clinical septic shock, the accumulated evidence shows that it reliably mimics Gram-negative sepsis. ${ }^{3}$ Another cytokine, IL- 6 , has recently been implicated in the pathophysiology of septic shock, ${ }^{19}$ and a report has also shown that it may play a role in endotoxin treated mice. ${ }^{20}$ In some instances, therefore, the 
effects of L-carnitine on serum IL-6 levels in our model of endotoxin shock were also evaluated.

\section{Materials and Methods}

Animals: Male C57BL/6 mice were purchased from Iffa-Credo (Lyon, France). Mice (6-7 weeks of age at the time of use) were housed in groups of eight, and were allowed food and water ad libitum. They were kept under specific pathogen-free conditions, and were randomly assigned to various treatment groups.

Drugs and chemicals: L-Carnitine as well as its derivatives were all synthesized by Sigma-Tau Chemical Laboratories (Pomezia, Italy). LPS (Escherichia coli 055:B5) was from Difco (Difco Laboratories, Detroit, MI, USA); actinomycin D-mannitol was from Sigma (Sigma Chemical Laboratories, St Louis, MO, USA). Recombinant murine TNF and recombinant murine IL-6 were both purchased from Genzyme (Boston, MA, USA). All chemicals were dissolved in pyrogen-free physiological saline solution just prior to use. Tritiated thymidine $\left({ }^{3} \mathrm{H}-\mathrm{TdR}, 5 \mathrm{Ci} / \mathrm{mmol}\right)$ was from Amersham (Aylesbury, Buckinghamshire, UK).

Cell lines and tissue culture media: The TNF-sensitive L929 cell line (a murine fibrosarcoma) was grown in RPMI-1640 medium containing $25 \mathrm{mM}$ HEPES and $2 \mathrm{mM}$ L-glutamine (Biochrom KG, Berlin, Germany) supplemented with $10 \%$ heat-inactivated Myoclone foetal calf serum (FCS) (Gibco, Grand Island, NY, USA), and $50 \mu \mathrm{g} / \mathrm{ml}$ gentamicin (Sigma). The murine hybridoma cell line B9, which is dependent on IL-6 for growth ${ }^{21}$ was maintained in the above culture medium with the further addition of $5.0 \times 10^{-5} \mathrm{M}$ 2-mercaptoethanol (Sigma) and $10 \mathrm{U} / \mathrm{ml}$ recombinant murine interleukin 6 (rmIL-6).

Endotoxaemia model: C57BL/6 mice received $30 \mathrm{mg} / \mathrm{kg}$ LPS intraperitoneally (i.p.), which had been predetermined to produce approximately $60 \%$ lethality. In the majority of experiments, animals were first pre-treated i.p. with L-carnitine derivatives $1 \mathrm{~h}$ before LPS injection, and then treated intravenously (i.v.) $10 \mathrm{~min}$ following LPS administration. However, other treatment protocols were also adopted, and they are reported in the relevant tables. Some animal physiological responses to endotoxaemia were graded such as food intake, body weight, mobility, amount of ocular exudate, and rectal temperature.

In particular, temperature measurements were taken with an electronic thermometer (model Babuc/M, I.S.I., Milan, Italy) with the appropriate thermistor (probe TM35S). Animal health state was classified as follows: very ill (body temperature below $32^{\circ} \mathrm{C}$, absence of mobility, marked body weight loss, abundant ocular exudate); fair (body temperature between 32 and $35^{\circ} \mathrm{C}$, poor mobility, small body weight loss, moderate ocular exudate); normal (body temperature above $35^{\circ} \mathrm{C}$, normal mobility, normal body weight, absence of ocular exudate). All groups of animals were examined at $24 \mathrm{~h}$ intervals after LPS injection to assess survival, and they were followed up to 10 days.

Serum TNF and IL-6 determinations: To determine circulating TNF and IL-6 levels, ether-anaesthetized mice were bled by retro-orbital sinus puncture at $1 \mathrm{~h}$ following $30 \mathrm{mg} / \mathrm{kg}$ LPS injection. Blood was allowed to clot at room temperature, and then centrifuged at $1000 \times \boldsymbol{g}$ for $15 \mathrm{~min}$. The separated serum was stocked and stored at $-80^{\circ} \mathrm{C}$ until assayed.

TNF bio-assay: Concentrations of TNF in serum were determined by using the L929 cytotoxicity assay described by Flick and Gifford ${ }^{22}$ with minor modifications. Briefly, $100 \mu \mathrm{l}$ of L929 cells $\left(3.2 \times 10^{5}\right.$ cells $\left./ \mathrm{ml}\right)$ in RPMI-1640 containing $10 \%$ FCS were seeded into each well of a flat-bottomed 96-well microtitre plate (Falcon, Becton \& Dickinson, Meylan Cedex, France) and incubated overnight at $37^{\circ} \mathrm{C}$ in a humidified atmosphere of $5 \% \mathrm{CO}_{2}$. After incubation, spent medium was discarded and two-fold serial dilutions (carried out in RPMI-1640 1\% FCS) of serum samples were added to the cells in the presence of actinomycin D-mannitol at a final concentration of $1 \mu \mathrm{g} / \mathrm{ml}$. The L929 cell cultures were then further incubated for $18 \mathrm{~h}$. Following incubation, the medium was discarded, and the plates were first washed twice with $0.9 \% \mathrm{NaCl}$ and then stained for $15 \mathrm{~min}$ at room temperature with $0.5 \%(\mathrm{w} / \mathrm{v})$ Crystal Violet in $20 \%$ ethanol and $8 \%$ formaldehyde. After discarding the stain, the wells were gently washed in running tap water; the dye which had been taken up was eluted with $33 \%$ acetic acid and the relative absorbance at $540 \mathrm{~nm}$ was measured with a Multiskan MCC/340 ELISA reader (Flow Laboratories, Mclean, VA, USA). TNF activity is expressed in units $/ \mathrm{ml}$, and is defined as the reciprocal of the dilution necessary to cause death of $50 \%$ of the actinomycin-treated control cells. Final TNF concentrations for each sample were calculated by interpolating the values of four to six sample dilutions.

IL-6 bio-assay: Levels of IL-6 in serum were measured by its ability to induce proliferation of the murine B-cell hybridoma line B9. ${ }^{21}$ B9 cells were washed twice prior to use in the assay in order to remove the exogenous rmIL-6 added to sustain their growth.

Briefly, two-fold serial dilutions of thawed sera in RPMI-1640 supplemented with 10\% FCS, 
$5.0 \times 10^{-5} \mathrm{M}$ 2-mercaptoethanol were added to flat-bottomed 96-well microtitre plates containing $5.0 \times 10^{3}$ cells per well. Cells were then incubated for $96 \mathrm{~h}$ at $37^{\circ} \mathrm{C}$ in a humidified atmosphere of $5 \%$ $\mathrm{CO}_{2}$, and pulsed with $0.5 \mu \mathrm{Ci} /$ well of ${ }^{3} \mathrm{H}-\mathrm{TdR}$ during the last $18 \mathrm{~h}$ of incubation. Afterwards, the cells were harvested onto glass fibre filtermats (Pharmacia, Turku, Finland) by using an automated cell harvester (Pharmacia), and ${ }^{3} \mathrm{H}-\mathrm{TdR}$ incorporation (an index of cell proliferation) was assessed by a $\beta$-plate counter (Pharmacia). IL-6 activity is expressed in B9 hybridoma growth units per $\mathrm{ml}$, and one unit is defined as the reciprocal of the sample dilution required to produce one halfmaximal proliferation. Values for each sample were calculated by interpolating the sample cpm of four to six dilutions by means of linear regression analysis.

Statistical analysis: Statistical analysis of TNF and IL-6 values was performed by using the Student's $t$-test, while survival data were assessed by Fisher's exact test.

\section{Results}

Physiological responses to endotoxin: LPS intraperitoneal injection in C57BL/6 mice (30 mg/kg body weight) provoked a considerable serum TNF release (Fig. 1). Systemic TNF secretion started as early as $0.5 \mathrm{~h}$ after LPS administration reaching a peak at $1 \mathrm{~h}$, and then declined to undetectable levels within the next $4 \mathrm{~h}$. Twenty-four hours following LPS challenge, animals exhibited decreased body weights paralleled by concomitant hypothermia, which lasted up to 3 days before they started to recover (Fig. 2). Furthermore, the animals given endotoxin showed an abundant ocular exudate, a dramatic decrease in food intake as well as a loss of mobility and, when touched, a comatose-dazed behaviour.

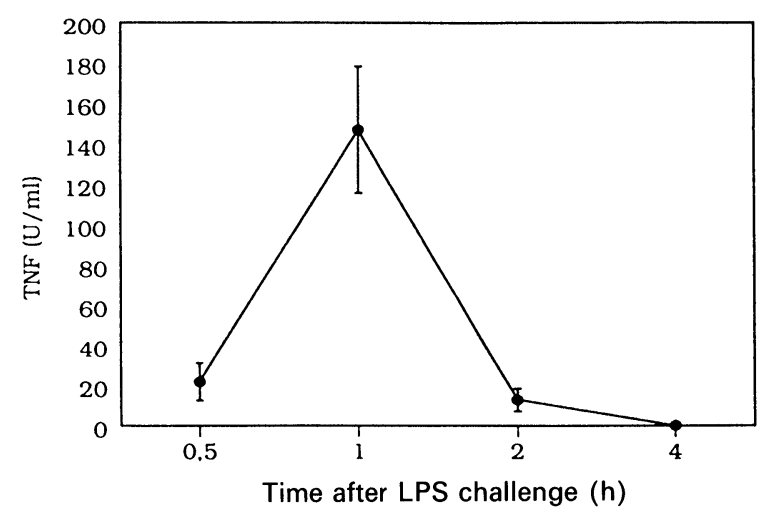

FIG.1. Time course of serum TNF concentration after i.p. administration of $30 \mathrm{mg} / \mathrm{kg}$ LPS to C57BL/6 mice. TNF was determined as detailed in Materials and Methods. Values are mean (four animals per group) \pm standard deviation.

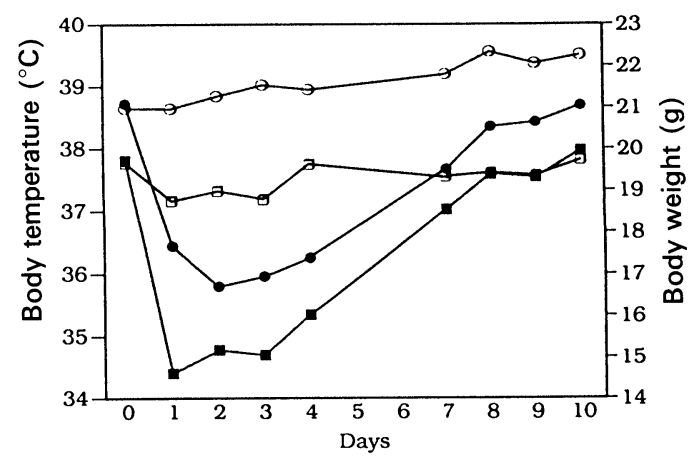

FIG.2. Variations in body temperature (squares) and body weight (circles) in control (open symbols) and LPS-challenged mice (closed symbols). Animals were checked up to 10 days after LPS administration at day $0(30 \mathrm{mg} / \mathrm{kg}$, i.p.).

L-carnitine and one derivative: L-Carnitine (ST 198) caused a marked decrease in serum TNF levels and, at the same time, induced an increased serum IL-6 release. The observed variation in TNF and IL-6 levels was statistically significant $(p<0.05)$, and was confirmed by a second experiment performed according to the same experimental protocol. Although L-carnitine significantly affected serum TNF and IL-6 release, it became clear that, at least at the doses employed in our protocol, it was not able to confer a significant protection upon the animals. In fact, only a small improvement in survival was observed, namely ten survivors in the ST 198-treated group $v s$. eight survivors in the LPS control. Similar results were obtained even with a protocol based on repeated L-carnitine administrations. The ST 784 derivative exerted similar effects both on serum TNF levels and survival, but, at variance with $\mathrm{L}$-carnitine, was unable to modulate IL-6 release (Table 1). Although the survival was not significantly increased after treatment with ST 198 and ST 784, it was found that both compounds markedly improved the health conditions of LPS-challenged mice as evaluated by food intake. The former compound, in particular, appeared to be more active in being able to induce a three-fold increase of food consumption with respect to the LPS control (Table 2).

Acetyl-L-carnitine and three derivatives: At the doses utilized throughout the experiments, neither acetyl-L-carnitine (ST 200) nor its derivatives were able to significantly modulate serum TNF release and survival, except ST 1025 which, although unable to affect the animal survival, was still capable of inducing a significant reduction $(p<0.001$; $p<0.01)$ in TNF levels in two different experiments. The lack of effects of ST 200 and ST 1025 on animal survival was also confirmed when both compounds were administered using the protocol based on multiple administrations. Interestingly, all 
Table 1. Effects of L-carnitine (ST 198) and its derivative (ST 784) on both serum TNF and IL-6 production, and lethality of mice challenged with LPS

\begin{tabular}{|c|c|c|c|c|c|c|c|c|}
\hline \multirow[b]{2}{*}{ Compound } & \multirow[b]{2}{*}{ Treatment } & \multicolumn{3}{|c|}{ TNF } & \multicolumn{3}{|c|}{ IL-6 } & \multirow{2}{*}{$\frac{\text { Lethality }}{\text { Dead/total }}$} \\
\hline & & $\begin{array}{c}\% \\
\text { variation }\end{array}$ & $\begin{array}{l}\text { No. } \\
\text { of mice }\end{array}$ & $p$ & $\begin{array}{c}\% \\
\text { variation }\end{array}$ & $\begin{array}{l}\text { No. } \\
\text { of mice }\end{array}$ & $p$ & \\
\hline ST 198 & $\begin{array}{l}1(50 \mathrm{mg} / \mathrm{kg}) \\
1(50 \mathrm{mg} / \mathrm{kg}) \\
2(50 \mathrm{mg} / \mathrm{kg})\end{array}$ & $\begin{array}{l}-57 \\
-64 \\
-\end{array}$ & $\begin{array}{l}8 \\
8 \\
-\end{array}$ & $\begin{array}{l}<0.05 \\
<0.05 \\
-\end{array}$ & $\begin{array}{c}+124 \\
+39 \\
-\end{array}$ & $\begin{array}{l}8 \\
8 \\
-\end{array}$ & $\begin{array}{l}<0.05 \\
<0.05 \\
-\end{array}$ & $\begin{array}{c}14 / 24(16 / 24) \\
6 / 10(8 / 10)\end{array}$ \\
\hline ST 784 & $\begin{array}{l}1(50 \mathrm{mg} / \mathrm{kg}) \\
2(50 \mathrm{mg} / \mathrm{kg})\end{array}$ & $\begin{array}{l}-36 \\
-\end{array}$ & $\begin{array}{l}24 \\
-\end{array}$ & $\begin{array}{c}<0.02 \\
-\end{array}$ & +19 & $\begin{array}{l}8 \\
-\end{array}$ & n.s. & $\begin{array}{l}9 / 16(11 / 16) \\
7 / 10(8 / 10)\end{array}$ \\
\hline
\end{tabular}

Treatments were performed by injecting LPS $30 \mathrm{mg} / \mathrm{kg}$ i.p. at time zero and administering the compounds, at the dose indicated as follows: 1) $-60 \mathrm{~min}$ i.p. and $+10 \mathrm{~min}$ i.v., 2) from day -1 to day +3 i.p. twice a day (once at day 0 ). Statistical significance $(p)$ was evaluated by the Student's $t$-test. Lethality of the LPS-treated group is indicated in brackets. ST $198=\mathrm{L}$-carnitine inner salt; ST $784=$ L-carnitine chloride ester with $\beta$-hydroxybutyric acid.

Table 2. Health conditions, evaluated by food intake of LPS-challenged mice following treatment with ST 198 and ST 784

\begin{tabular}{lccc}
\hline \multicolumn{1}{c}{ Compound } & $\begin{array}{c}\text { Food } \\
\text { consumed } \\
(\mathbf{g})\end{array}$ & $\begin{array}{c}\text { Cumulative } \\
\text { survival } \\
\text { (d) }\end{array}$ & $\begin{array}{c}\text { Food consumed per } \\
\text { animal per day } \\
\text { of survival }\end{array}$ \\
\hline Untreated control & 311 & 100 & 3.11 \\
LPS control & 51 & 40 & 1.28 \\
ST 198 & 158 & 53 & 2.98 \\
ST 784 & 105 & 49 & 2.14 \\
\hline
\end{tabular}

Mice (ten animals per group) were treated with ST 198 (50 $\mathrm{mg} / \mathrm{kg}$, i.p.) and with ST $784(50 \mathrm{mg} / \mathrm{kg}$, i.p.), twice daily but once at day 0 , starting from day -1 to day +3 , with respect to the LPS challenge (day 0 ). Control groups were either injected with $30 \mathrm{mg} / \mathrm{kg}$ LPS (LPS control) or treated twice a day with saline from day -1 through day +3 (untreated control). Animals were followed up to $10 \mathrm{~d}$ after LPS injection. Food consumed during this time as well as cumulative survival (referred to as the sum of the days of survival of each single mouse within a group) were evaluated. The ratio of the former and the latter parameter yields the food consumed per animal per day of survival (right-end column). the compounds belonging to this class caused a significant increase in serum IL-6 release (Table 3).

Propionyl-L-carnitine and three derivatives: Although propionyl-L-carnitine (ST 261) and its derivatives were all able to decrease serum TNF levels, their effect was not statistically significant. The only exception was ST 780, which lowered $(p<0.02)$ serum TNF release when the treatment schedule included an i.v. administration. No significant changes in serum IL-6 levels were observed in LPS-treated mice following administration with ST 261 and ST 780. All compounds belonging to this class were unable to reduce the LPS-induced lethality, at least at the doses utilized in the experiments (Table 4).

Isobutyryl-L-carnitine and two derivatives: Even though the parent compound (ST 284) was not able to influence serum TNF release, its derivatives ST 730

Table 3. Effects of acetyl-L-carnitine chloride (ST 200) and its derivatives (ST 857, ST 943, ST 1025) on both serum TNF and IL-6 production, and lethality of mice challenged with LPS

\begin{tabular}{|c|c|c|c|c|c|c|c|c|}
\hline \multirow[b]{2}{*}{ Compound } & \multirow[b]{2}{*}{ Treatment } & \multicolumn{3}{|c|}{ TNF } & \multicolumn{3}{|c|}{ IL-6 } & \multirow{2}{*}{$\frac{\text { Lethality }}{\text { Dead/total }}$} \\
\hline & & $\begin{array}{c}\% \\
\text { variation }\end{array}$ & $\begin{array}{c}\text { No. } \\
\text { of mice }\end{array}$ & $p$ & $\begin{array}{c}\% \\
\text { variation }\end{array}$ & $\begin{array}{c}\text { No. } \\
\text { of mice }\end{array}$ & $p$ & \\
\hline ST 200 & $\begin{array}{l}1(50 \mathrm{mg} / \mathrm{kg}) \\
1(50 \mathrm{mg} / \mathrm{kg}) \\
2(50 \mathrm{mg} / \mathrm{kg})\end{array}$ & $\begin{array}{l}-26 \\
-52 \\
-\end{array}$ & $\begin{array}{l}8 \\
8 \\
-\end{array}$ & $\begin{array}{l}\text { n.s. } \\
\text { n.s. } \\
-\end{array}$ & $\begin{array}{l}+61 \\
+20 \\
-\end{array}$ & $\begin{array}{l}8 \\
8 \\
-\end{array}$ & $\begin{array}{c}<0.01 \\
<0.02 \\
-\end{array}$ & $\begin{array}{l}9 / 16(10 / 16) \\
7 / 10(8 / 10)\end{array}$ \\
\hline ST 857 & $1(50 \mathrm{mg} / \mathrm{kg})$ & -11 & 16 & n.s. & +45 & 8 & $<0.01$ & $10 / 16(9 / 16)$ \\
\hline ST 943 & $\begin{array}{l}1(50 \mathrm{mg} / \mathrm{kg}) \\
1(50 \mathrm{mg} / \mathrm{kg})\end{array}$ & $\begin{array}{r}+24 \\
+5\end{array}$ & $\begin{array}{r}8 \\
16\end{array}$ & $\begin{array}{l}\text { n.s. } \\
\text { n.s. }\end{array}$ & +105 & 8 & $<0.001$ & $13 / 16(10 / 16)$ \\
\hline ST 1025 & $\begin{array}{l}1(15 \mathrm{mg} / \mathrm{kg}) \\
1(15 \mathrm{mg} / \mathrm{kg}) \\
2(15 \mathrm{mg} / \mathrm{kg})\end{array}$ & $\begin{array}{c}-60 \\
-74 \\
-\end{array}$ & $\begin{array}{r}16 \\
8 \\
-\end{array}$ & $\begin{array}{c}<0.001 \\
<0.01 \\
-\end{array}$ & $\begin{array}{l}+73 \\
-\end{array}$ & $\begin{array}{l}8 \\
-\end{array}$ & $\begin{array}{c}<0.001 \\
-\end{array}$ & $\begin{array}{c}11 / 16(10 / 16) \\
7 / 10(8 / 10)\end{array}$ \\
\hline
\end{tabular}

Treatments were performed by injecting LPS $30 \mathrm{mg} / \mathrm{kg}$ i.p. at time zero and administering the compounds, at the dose indicated, as follows: 1) $-60 \mathrm{~min}$ i.p. and $+10 \mathrm{~min}$ i.v., 2) from day -1 to day +3 i.p. twice a day (once at day 0 ). Statistical significance $(p)$ was evaluated by the Student's $t$-test. Lethality of the LPS-treated group is indicated in brackets. ST $200=$ acetyl-L-carnitine chloride; ST 857 = acetyl-L-carnitine chloride amide with arginine hydrochloride; ST $943=$ acetyl-L-carnitine tartrate acid ester with $\gamma$-hydroxybutyric acid; ST $1025=$ acetyl-L-carnitine amide with citrulline. 
Table 4. Effects of propionyl-L-carnitine chloride (ST 261) and its derivatives (ST 780, ST 880, ST 921) on both serum TNF and IL-6 production, and lethality of mice challenged with LPS

\begin{tabular}{|c|c|c|c|c|c|c|c|c|}
\hline \multirow[b]{2}{*}{ Compound } & \multirow[b]{2}{*}{ Treatment } & \multicolumn{3}{|c|}{ TNF } & \multicolumn{3}{|c|}{ IL-6 } & \multirow{2}{*}{$\frac{\text { Lethality }}{\text { Dead/total }}$} \\
\hline & & $\begin{array}{c}\% \\
\text { variation }\end{array}$ & $\begin{array}{l}\text { No. } \\
\text { of mice }\end{array}$ & $p$ & $\begin{array}{c}\% \\
\text { variation }\end{array}$ & $\begin{array}{l}\text { No. } \\
\text { of mice }\end{array}$ & $p$ & \\
\hline ST 261 & $\begin{array}{l}1(50 \mathrm{mg} / \mathrm{kg}) \\
1(50 \mathrm{mg} / \mathrm{kg})\end{array}$ & $\begin{array}{l}-37 \\
-48\end{array}$ & $\begin{array}{l}8 \\
8\end{array}$ & $\begin{array}{l}\text { n.s. } \\
\text { n.s. }\end{array}$ & $\begin{array}{l}+1 \\
-2\end{array}$ & $\begin{array}{l}8 \\
8\end{array}$ & $\begin{array}{l}\text { n.s. } \\
\text { n.s. }\end{array}$ & $5 / 8(6 / 7)$ \\
\hline ST 780 & $\begin{array}{l}1(50 \mathrm{mg} / \mathrm{kg}) \\
3(50 \mathrm{mg} / \mathrm{kg}) \\
2(50 \mathrm{mg} / \mathrm{kg})\end{array}$ & $\begin{array}{l}-62 \\
-30 \\
-\end{array}$ & $\begin{array}{l}8 \\
5 \\
-\end{array}$ & $\begin{array}{c}<0.02 \\
\text { n.s. } \\
-\end{array}$ & $\begin{array}{l}+8 \\
+6 \\
-\end{array}$ & $\begin{array}{l}8 \\
5 \\
-\end{array}$ & $\begin{array}{l}\text { n.s. } \\
\text { n.s. } \\
-\end{array}$ & $\begin{array}{l}3 / 8(1 / 8) \\
5 / 8(5 / 8)\end{array}$ \\
\hline ST 880 & $1(50 \mathrm{mg} / \mathrm{kg})$ & -51 & 8 & n.s. & & & & $6 / 7(5 / 7)$ \\
\hline ST 921 & $1(50 \mathrm{mg} / \mathrm{kg})$ & -47 & 8 & n.s. & & & & $6 / 8(6 / 7)$ \\
\hline
\end{tabular}

Treatments were performed by injecting LPS $30 \mathrm{mg} / \mathrm{kg}$ i.p. at time zero and administering the compounds, at the dose indicated, as follows: 1) $-60 \mathrm{~min}$ i.p. and $+10 \mathrm{~min}$ i.v., 2) from day -1 to day +3 i.p. twice a day (once at day 0 ); 3 ) -60 min i.p. and +10 i.p. Statistical significance $(p)$ was evaluated by the Student's $t$-test. Lethality of the LPS-treated group is indicated in brackets. ST 261 = propionyl-L-carnitine chloride; ST $780=$ propionyl-L-carnitine chloride ester with $\beta$-hydroxybutyric acid; ST $880=$ propionyl-L-carnitine chloride ester with $\gamma$-hydroxybutyric acid; ST $921=$ propionyl-L-carnitine chloride amide with arginine hydrochloride.

and ST 878 significantly reduced $(p<0.05)$ TNF levels. No differences in serum IL-6 levels were found in mice intoxicated with LPS and treated with ST 284 and ST 878. The survival of LPS-challenged mice was not improved following administration of any of these compounds (Table 5).

Isovaleryl-L-carnitine and six derivatives: Among the compounds belonging to this class, only two derivatives, namely ST 687 and ST 1037, were effective in significantly reducing $(p<0.05)$ serum TNF levels (Table 6). Even if none of the investigated compounds significantly improved the survival of the LPS-challenged mice, isovaleryl-Lcarnitine (ST 551) administration still allowed a better recovery of health conditions of survived mice. The class distributions of the animal health state, based on animal body temperature and evaluated at different days after treatment, are shown in Fig. 3.

\section{Discussion}

Septic shock is an increasingly serious health problem in hospitals, especially in intensive care units, despite the use of multiple antibiotics, surgical drainage, and intervention including vasopressor and metabolic support. It was estimated that this disease causes 100000 deaths annually in the United States. ${ }^{23}$ It is generally accepted that the primary mediator of the pathophysiological changes occurring in Gramnegative sepsis is LPS, which in turn stimulates host macrophages to produce a cascade of endogenous mediators responsible for many alterations in host physiology. There are many reports showing that

Table 5. Effects of isobutyryl-L-carnitine (ST 284) and its derivatives (ST 730, ST 878) on both serum TNF and IL-6 production, and lethality of mice challenged with LPS

\begin{tabular}{|c|c|c|c|c|c|c|c|c|}
\hline \multirow[b]{2}{*}{ Compound } & \multirow[b]{2}{*}{ Treatment } & \multicolumn{3}{|c|}{ TNF } & \multicolumn{3}{|c|}{ IL-6 } & \multirow{2}{*}{$\frac{\text { Lethality }}{\text { Dead/total }}$} \\
\hline & & $\begin{array}{c}\% \\
\text { variation }\end{array}$ & $\begin{array}{l}\text { No. } \\
\text { of mice }\end{array}$ & $p$ & $\begin{array}{c}\% \\
\text { variation }\end{array}$ & $\begin{array}{c}\text { No. } \\
\text { of mice }\end{array}$ & $p$ & \\
\hline ST 284 & $1(50 \mathrm{mg} / \mathrm{kg})$ & -6 & 16 & n.s. & +12 & 8 & n.s. & $6 / 8(3 / 8)$ \\
\hline ST 730 & $\begin{array}{l}1(50 \mathrm{mg} / \mathrm{kg}) \\
2(50 \mathrm{mg} / \mathrm{kg})\end{array}$ & $\begin{array}{c}-51 \\
-\end{array}$ & $\begin{array}{c}7 \\
-\end{array}$ & $\begin{array}{c}<0.05 \\
-\end{array}$ & - & - & - & $5 / 8(6 / 8)$ \\
\hline ST 878 & $\begin{array}{l}1(50 \mathrm{mg} / \mathrm{kg}) \\
2(50 \mathrm{mg} / \mathrm{kg})\end{array}$ & $\begin{array}{c}-51 \\
-\end{array}$ & $\begin{array}{c}8 \\
-\end{array}$ & $\begin{array}{c}<0.05 \\
-\end{array}$ & -23 & $\begin{array}{l}8 \\
-\end{array}$ & - & $2 / 8(3 / 8)$ \\
\hline
\end{tabular}

Treatments were performed by injecting LPS $30 \mathrm{mg} / \mathrm{kg}$ i.p. at time zero and administering the compounds, at the dose indicated, as follows: 1) $-60 \mathrm{~min}$ i.p. and $+10 \mathrm{~min}$ i.v., 2) from day -1 to day +3 i.p. twice a day (once at day 0 ). Statistical significance $(p)$ was evaluated by the Student's $t$-test. Lethality of the LPS-treated group is indicated in brackets. ST $284=$ isobutyryl-L-carnitine chloride; ST $730=$ isobutyryl-L-carnitine chloride ester with $\beta$-hydroxybutyric acid; ST $878=$ isobutyryl-L-carnitine ester with $\gamma$-hydroxybutyric acid. 
Table 6. Effects of isovaleryl-L-carnitine chloride (ST 551) and its derivative (ST 743, ST 687, ST 994, ST 803 , ST 899 , ST 1037) on serum TNF production, and lethality of mice challenged with LPS

\begin{tabular}{|c|c|c|c|c|c|}
\hline \multirow[b]{2}{*}{ Compound } & \multirow[b]{2}{*}{ Treatment } & \multicolumn{3}{|c|}{ TNF } & \multirow{2}{*}{$\begin{array}{l}\text { Lethality } \\
\text { Dead/total }\end{array}$} \\
\hline & & $\begin{array}{c}\% \\
\text { variation }\end{array}$ & $\begin{array}{l}\text { No. } \\
\text { of mice }\end{array}$ & $p$ & \\
\hline ST 551 & $1(50 \mathrm{mg} / \mathrm{kg})$ & -25 & 16 & n.s. & $11 / 24(14 / 24)$ \\
\hline ST 743 & $1(50 \mathrm{mg} / \mathrm{kg})$ & -23 & 8 & n.s. & $6 / 8(6 / 8)$ \\
\hline ST 687 & $\begin{array}{c}1(50 \mathrm{mg} / \mathrm{kg}) \\
2(200 \mathrm{mg} / \mathrm{kg})\end{array}$ & -44 & $\begin{array}{l}8 \\
-\end{array}$ & $<0.05$ & $\begin{array}{l}5 / 8(7 / 8) \\
8 / 8(4 / 8)\end{array}$ \\
\hline ST 944 & $1(50 \mathrm{mg} / \mathrm{kg})$ & +29 & 8 & n.s. & $5 / 8(7 / 8)$ \\
\hline \multirow[t]{2}{*}{ ST 803} & $\begin{array}{c}1(5 \mathrm{mg} / \mathrm{kg} \text { i.p. } \\
\text { and } \\
1 \mathrm{mg} / \mathrm{kg} \text { i.v. })\end{array}$ & +16 & 8 & n.s. & $8 / 8(4 / 8)$ \\
\hline & $4(5 \mathrm{mg} / \mathrm{kg})$ & - & - & - & $3 / 5(5 / 7)$ \\
\hline ST 899 & $1(5 \mathrm{mg} / \mathrm{kg})$ & -27 & 8 & n.s. & $6 / 8(6 / 8)$ \\
\hline ST 1037 & $\begin{array}{c}1 \text { (5 mg/kg i.p. } \\
\text { and } \\
1 \mathrm{mg} / \mathrm{kg} \text { i.v. })\end{array}$ & -44 & 8 & $<0.05$ & $5 / 8(5 / 8)$ \\
\hline
\end{tabular}

Treatments were performed by injecting LPS $30 \mathrm{mg} / \mathrm{kg}$ i.p. at time zero and administering the compounds, at the dose indicated, as follows: 1) $-60 \mathrm{~min}$ i.p. and $+10 \mathrm{~min}$ i.v., 2) from day -1 to day +3 i.p. twice a day (once at day 0$) ; 4)-60 \mathrm{~min}$ i.p. Statistical significance $(p)$ was evaluated by the Student's $t$-test. Lethality of the LPS-treated group is indicated in brackets. ST $551=$ isovaleryl-L-carnitine chloride; ST $743=$ isovaleryl-L-carnitine tartrate acid ester with $\gamma$-hydroxybutyric acid; ST $803=$ isovaleryl-L-carnitine bromide ester with Z-3-(6-chloro)phthalidiliden-ethanol; ST $899=$ isovaleryl-L-carnitine bromide ester with Z-3-(5-chloro)phthalidiliden-ethanol; ST $1037=$ isovaleryl-L-carnitine chloride ester with dodecanol.

over-production of several cytokines such as IL-1, IL- 6 , TNF, and IFN- $\gamma$ is associated with severe sepsis. Among these cytokines, however, TNF has been shown to play a key role in many metabolic derangements occurring during septic shock, ${ }^{24}$ and its abnormally high serum levels are often correlated with poor prognosis. ${ }^{25,26}$ Moreover, TNF can also be found in the serum of animals experimentally intoxicated with LPS and additionally causes, when injected in animals, a toxic syndrome indistinguishable from endotoxaemia. ${ }^{27-29}$
Experimentally induced endotoxin shock in laboratory animals, although it does not exactly reproduce all the alterations of septic shock, has become a valuable and very convenient model for studying sepsis. In fact, it reliably mimics many physiological as well as immunological dysregulations occurring in this disease. ${ }^{24}$

By using this model, the authors found that LPS injection in mice caused a dramatic reduction in body temperature. This decrease was evident no sooner than $24 \mathrm{~h}$ following LPS administration and

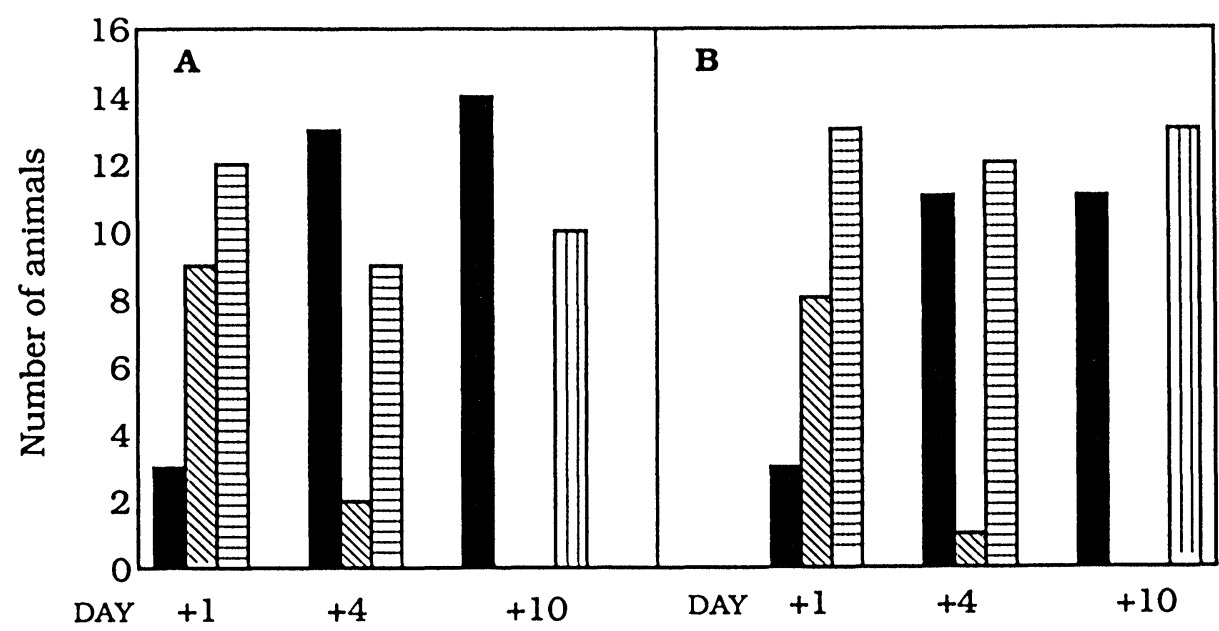

FIG. 3. Health conditions, as evaluated by body temperature, at days $+1,+4$ and +10 of LPS-injected mice treated either with saline (panel A) or with isovaleryl-L-carnitine (panel B) according to the treatment

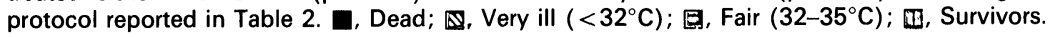


lasted for two more days. During this time, the LPS-injected mice were very sick, and they started to recover only from the fourth day after LPS challenge.

At variance with this finding, other investigators reported an increase in body temperature in different animal models ${ }^{30,31}$ as well as in humans ${ }^{32}$ following LPS injection. In agreement with our results, however, Pogrebniak et $a l^{33}$ found that $\mathrm{C} 3 \mathrm{H} / \mathrm{HeN}$ mice injected with LPS (30 mg/kg, i.p.) were markedly hypothermic. Additionally, Handley et $a .^{34}$ made similar observations in $\mathrm{Balb} / \mathrm{c}$ mice injected i.v. with $10 \mathrm{mg} / \mathrm{kg}$ LPS. From these studies, it can be argued that hypothermia is a typical physiological response of mice to LPS and appears to be independent of the strain used. In the present model, moreover, smaller decreases in body temperature were observed when lower doses of LPS (down to $0.3 \mathrm{mg} / \mathrm{kg}$ ) were employed, while a dose as low as $0.03 \mathrm{mg} / \mathrm{kg}$ was completely ineffective (data not shown). Furthermore, the decrease in body temperature was paralleled by a concomitant body weight loss, which appeared to be related to the dose of LPS (data not shown). The maximum decrease of body weight was observed $48 \mathrm{~h}$ after LPS challenge, then the mice slowly began to recover their normal weight. Taken together, these data indicate that body temperature and body weight are valuable parameters to monitor health conditions of mice during endotoxaemia. In a preliminary experiment, performed to ascertain the time course of TNF production, it was found that serum TNF peaked as early as $1 \mathrm{~h}$ following LPS injection, and became undetectable by $4 \mathrm{~h}$. This result is consistent with similar studies reported by other investigators in different animal models ${ }^{35-37}$ and in humans. ${ }^{32}$

In this experimental model L-carnitine and some acyl derivatives were tested for possible protective effects in LPS-challenged mice. A role of L-carnitine in the treatment of sepsis was first suggested by Border et al., ${ }^{38}$ who hypothesized that some septic processes might be associated with an impairment of lipid oxidation due to systemic depletion of L-carnitine. ${ }^{38}$ Support to this hypothesis was lent by different investigators, who observed a significant improvement in survival of LPS-challenged animals following treatment with L-carnitine. ${ }^{39,40}$

In this LPS shock model, L-carnitine and its derivative ST 784 were able to reduce serum TNF levels, although this decrease was not always statistically significant. Similarly, the compounds derived from propionyl-L-carnitine and isobutyrylL-carnitine were effective in reducing serum TNF release in LPS-challenged mice. In contrast, only two isovaleryl-L-carnitine derivatives, namely ST 687 and ST 1037, were found to significantly decrease TNF levels. However, L-carnitine and
isovaleryl-L-carnitine, which differently affected serum TNF levels, were both able to improve health conditions of LPS-injected mice and to lightly reduce lethality as well. Different treatment schedules and different dosages may be necessary to ascertain the real therapeutic potential of these compounds in counteracting LPS intoxication.

The authors found that serum TNF and IL-6 levels were modulated differently by treatment with L-carnitines. In fact, in most cases where serum TNF was significantly decreased, concomitant significantly high levels of serum IL-6 were observed. This is of interest in the light of the suggestion that IL-6 may act as a negative modulator of TNF production. ${ }^{30,41}$ In addition, IL-6 was found to induce hyporesponsiveness to endotoxin in mice, ${ }^{42}$ and to inhibit the release of TNF in mice as well as in human U937 cells and monocytes in vitro. ${ }^{43}$ Furthermore, it is known that TNF and IL-6 synthesis is regulated differently by various agents. High c-AMP levels, for example, were reported to inhibit TNF synthesis while inducing IL-6 production. ${ }^{4-45}$ Additionally, Marcinkiewicz ${ }^{46}$ observed that the production of these cytokines by murine peritoneal macrophages was affected differently by prostaglandins $\mathrm{PGE}_{2}$ and $\mathrm{PGI}_{2}$. In fact, while both prostaglandins inhibited the release of TNF, they increased IL- 6 production at the same time.

It would be tempting to speculate, therefore, that L-carnitines might increase prostaglandin synthesis and c-AMP levels, the latter either directly or via prostaglandins, thereby decreasing TNF synthesis and increasing IL-6 levels. IL-6 in turn would further dampen the production of TNF.30,41 Although additional investigations are needed, reports showing that L-carnitine and some of its congeners were able to positively affect prostaglandins release from macrophages ${ }^{47}$ support this hypothesis.

Although TNF release has been reported to be a prominent event during endotoxaemia, ${ }^{2,5,36,48}$ the authors' results also point out that TNF by itself cannot be the only crucial mediator of lethality. In fact, it was found that the significant reductions in TNF levels brought about by several L-carnitine derivatives were not correlated with a significant reduction of lethality, though prolongation of mean survival time (data not shown) and ameliorated health conditions of treated animals were observed. The involvement of other critical factors in addition to TNF is supported by several studies showing that TNF by itself is necessary, although not sufficient, to cause lethality during endotoxaemia $^{4,8,49,50}$

Even though many questions concerning the ultimate molecular mechanism of action of L-carnitines in endotoxaemia are yet to be answered, 
it is envisaged that these compounds may be helpful, when associated with conventional therapy, in that they can effectively reduce TNF levels and ameliorate the host's metabolic processes. In conclusion, these results would justify clinical trials with L-carnitine in the treatment of sepsis. Indeed, preliminary reports ${ }^{12,51}$ indicate that early supplementation of L-carnitine in the therapy of septicaemia appears to counteract the onset of the metabolic cascade leading to septic shock.

\section{References}

1. Parrillo JE. Septic shock in humans: advances in the understanding of pathogenesis, cardiovascular dysfunction, and therapy. Ann Intern Med 1990; 113: $227-242$.

2. Glauser MP, Zanetti G, Baumgartner JD, Cohen J. Septic shock: pathogenesis. Lancet 1991; 338: 732-736.

3. Dunn DL. Role of endotoxin and host cytokines in septic shock. Chest 1991; 100: $164 \mathrm{~S}-168 \mathrm{~S}$.

4. Tracey KJ, Fong Y, Hesse DG, et al. Anti-cachectin/TNF monoclonal antibodies prevent septic shock during lethal bacteremia. Nature 1987; 330 662-664.

5. Beutler B, Cerami A. The endogenous mediator of endotoxic shock. Clin Res 1987; 35: 192-197.

6. Cerami A, Ikeda Y, Le Trang N, Hotez PJ, Beutler B. Weight loss associated with an endotoxin-induced mediator from peritoneal macrophages: the role of cachectin (tumour necrosis factor). Immunol Lett 1985; 11: 173-177.

7. Klosterhalfen B, Horstmann-Jungemann K, Vogel P, et al. Time course of various inflammatory mediators during recurrent endotoxemia. Biochem Pharmacol 1992; 43: 2103-2109.

8. Calandra T, Baumgartner JD, Grau GE, et al. Prognostic values of tumor necrosis factor/cachectin, IL-1, IFN $\alpha$ and IFN $\gamma$ in the serum of patients with septic shock. J Infect Dis 1990; 161: 982-987.

9. Fong Y, Tracey, KJ, Moldawer LL, et al. Antibodies to cachectin/TNF reduce IL- $1 \beta$ and IL- 6 appearance during lethal bacteraemia. $J$ Exp Med 1989; 170: $1627-1633$.

10. Shaunak S, Wendon J, Monteil M, Gordon AM. Septic scarlet fever due to Streptococcus pyogenes cellulitis. Q J Med 1988; 69: 921-925.

11. Marks JD, Marks CD, Luce JM. Plasma tumour necrosis factor in patients with septic shock. Mortality rate, incidence of adult respiratory distress syndrome and effects of methyl-prednisolone administration. Am Rev Respir Dis 1990; 141: 94-97.

12. Nanni G, Pittiruti M, Giovannini I, Boldrini G, Ronconi P, Castagneto M Plasma carnitine levels and urinary excretion during sepsis. J Parenter Enteral Nutr 1985; 9: 483-490.

13. Kirijama $M$. Effect of $L$-carnitine administration on lipid utilization in sepsis J Juzen Med Soc 1986; 95: 619-632.

14. Davis TA, Crady SK, Strong SA, et al. Increased acylcarnitine clearance and excretion in septic rats. Biomed Biocbim Acta 1991; 1: 81-86.

15. Bremer J. Carnitine. Metabolism and function. Physiol Rev 1983; 63: $1420-1480$.

16. Schinetti ML, Mazzini A. Effect of L-carnitine on human neutrophil activity. Int J Tiss Reac 1986; 8: 199-203.

17. Fieren MWJA, Bemd van den, GJCM, Ben-Efraim S, Bonta IL. Prostaglandin E2 inhibits the release of tumour necrosis factor- $\alpha$ rather than interleukin $1 \beta$ from human macrophages. Immunol Lett 1991; 31: 85-90.

18. Strieter RM, Remick DG, Ward PA, et al. Cellular and molecular regulation of tumour necrosis factor-alpha production by pentoxifylline. Biochem Biopbys Res Commun 1988; 155: 1230-1236.

19. Waage A, Brandtzaeg P, Halstensen A, Kierulf P, Espevik T. The complex pattern of cytokines in serum from patients with meningococcal septic shock. $J$ Exp Med 1989; 169: 333-338.

20. Kelly NM, Cross AS. Interleukin 6 is a better marker of lethality than tumour necrosis factor in endotoxin treated mice. FEMS Microbial Immunol 1992; 89: 317-322.

21. Aarden L, DeGroot ER, Schaap OL, Lansdorp PM. Production of hybridoma growth factor by human monocytes. Eur J Immunol 1987; 17: 1411-1416.

22. Flick DA, Gifford GE. Comparison of in vitro cell cytotoxic assays for tumour necrosis factor. I Immunol Metb $1984 ; 68$ : 167-175.

23. Cohen J, Glauser MP. Septic shock: treatment. Lancet 1991; 338: 736-739.

24. Starnes HF, Warren RS, Jeevanandam M, et al. Tumour necrosis factor and the acute metabolic response to tissue injury in man. J Clin Invest 1988; 82 1321.

25. Dames P, Reuter A, Gysen P, Demonty J, Lamy M, Franchimont P. Tumour necrosis factor and interleukin-1 serum levels during severe sepsis in humans. Crit Care Med 1989; 17: 975-978.
26. Debets JMH, Kampmeijer R, van der Linden MPMH, Buurman WA, van der Linden CJ. Plasma tumour necrosis factor and mortality in critically ill septic patients. Crit Care Med 1989; 17: 489-494.

27. Natanson C, Eichenhols PW, Danner RL. Endotoxin and tumour necrosi factor challenges in dogs simulate the cardiovascular profile of human septic shock. J Exp Med 1989; 169: 823-832.

28. Beutler B, Milsark IW, Cerami A. Passive immunization against cachectin/tumour necrosis factor protects mice from lethal effect of endotoxin. Science 1985; 229: 869-871.

29. Vassalli P. The pathophysiology of tumour necrosis factors. Annu Rev Immunol 1992; 10: 411-452.

30. Flohé S, Heinrich PC, Schneider J, Wendel A, Flohé L. Time course of IL-6 and TNF $\alpha$ release during endotoxin-induced endotoxin tolerance in rats. Biochem Pharmacol 1991; 41: 1607-1614.

31. Mozes T, Ben-Efraim S, Tak CJAM, Heiligers JPC, Saxena PR, Bonta IL Serum levels of tumour necrosis factor determine the fatal or non fatal course of endotoxic shock. Immunol Lett 1991; 27: 157-162.

32. Michie HR, Manogue KR, Spriggs DR, et al. Detection of circulating tumou necrosis factor after endotoxin administration. $N$ Engl J Med 1988; 318 1481-1486.

33. Pogrebniak HW, Merino MJ, Hahn SM, Mitchell JB, Pass HI. Spin trap salvage from endotoxaemia - the role of cytokine down-regulation. Surgery 1992; 112: 130-139

34. Handley DA, Van Valen RG, Melden MK, Houlihan WJ, Saunders RN Biological effects of the orally active platelet activating factor receptor antagonist SDZ 64-412. J Pharmacol Exp Ther 1988; 247: 617-623.

35. Niehorster $M$, Schonharting $M$, Wendel A. A novel xanthine derivative counteracting in vivo tumour necrosis factor-alpha toxicity in mice. Circulator shock 1992; 37: 270-273.

36. Smith III EF, Slivjak M J, Bartus O, Esser KM. SK\&F 86002 inhibits tumour necrosis factor formation and improves survival in endotoxaemic rats. $J$ Cardiovasc Pharmacol 1991; 18: 721-728.

37. Weinberg JR, Boyle P, Meager A, Guz A. Lipopolysaccharide, tumour necrosis factor, and interleukin-1 interact to cause hypotension. J Lab Clin Med 1992; 120: 205-211.

38. Border JR, Burns GP, Rumph C, Shenk WGjr. Carnitine levels in severe infection and starvation: a possible key to the prolonged catabolic state. Surgery 1970; 68: 175-179.

39. Takeyama N, Takagi D, Matsuo N, Kitazawa Y, Tanaka T. Altered hepatic fatty acid metabolism in endotoxicosis: effect of L-carnitine on survival. $A m$ $J$ Physiol 1989; 256: E31-E38.

40. Yoshitake J, Nomoto Y, Kono S, et al. Metabolic deterioration in shock state and its modulation. In: Molecular and cellular aspects of shock and trauma. New York: Alan R. Liss, 1983: 21-38.

41. Rola-Pleszczynski M, Stankova J. Cytokine gene regulation by $\mathrm{PGE}_{2}, \mathrm{LTB}_{4}$ and PAF. Mediat Inflamma 1992; 1: 5-8.

42. Van der Meer JWM, Helle M, Aarden A. Comparison of the effect of recombinant interleukin 6 and recombinant interleukin 1 on nonspecific resistance to infection. Eur I Immunol 1989; 19: 413-416.

43. Aderka D, Le J, Vilcek J. IL-6 inhibits lipopolysaccharide-induced tumou necrosis factor production in cultured human monocytes, U937 cells, and in mice. J Immunol 1989; 143: 3517-3523.

44. Katakami Y, Nakao Y, Koizumi NT, Katakami N, Ogawa R, Fujita T. Regulation of tumour necrosis factor production by mouse peritoneal macrophages: the role of cellular cyclic AMP. Immunology 1988; 64: 719-724.

45. Zhang Y, Lin JX, Vilcek J. Synthesis of interleukin 6 (interferon-beta $2 / B$ cell stimulatory factor 2) in human fibroblasts is triggered by an increase in intracellular cyclic AMP. J Biol Chem 1988; 263: 6177-6182.

46. Marcinkiewicz J. In vitro cytokine release by activated murine peritoneal macrophages: role of prostaglandins in the differential regulation of tumour necrosis factor alpha, interleukin 1, and interleukin 6. Cytokine 1991; 3 327-332.

47. Elliott GR, Lauwen APM, Bonta IL. The effect of acute feeding of carnitine and propionyl carnitine on basal and A23187-stimulated eicosanoid release from rat carrageenin-elicited peritoneal macrophages. Br J Nutr 1990; 64 497-503.

48. Girardin E, Grau GE, Dayer JM, et al. Tumour necrosis factor and interleukin-1 in the serum of children with severe infectious purpura. $N$ Engl $J$ Med 1988; 319: 397-400.

49. Franks AK, Kujawa KI, Yaffe LJ. Experimental elimination of tumou necrosis factor in low-dose endotoxin models has variable effects on survival. Infection and Immunity 1991; 59: 2609-2614.

50. Feuerstein G, Hallenbeck JM, Vanatta B, Rabinovici R, Perera PY, Vogel $\mathrm{SN}$. Effect of Gram-negative endotoxin on levels of serum corticosterone, TNF $\alpha$, circulating blood cells, and the survival of rats. Circ Shock 1990; 30 265-278.

51. Scaglione F, Cogo R, Mascola S, Fraschini F. Use of L-carnitine in patient affected by sepsis. Argomenti di Chemioantibiotico Terapia 1992; 2: 210-215.

ACKNOWLEDGEMENTS. Dr F. Beltrami is gratefully acknowledged for artwork and for editing this manuscript. The excellent technical assistance of Mrs C. Chiapparino, Mrs S. Manganello, Mrs M. L. Pacello, Mrs V. Parrella, Ms B. Leoni, Mr A. Marconi and Mr A. Rosi is also acknowledged. 


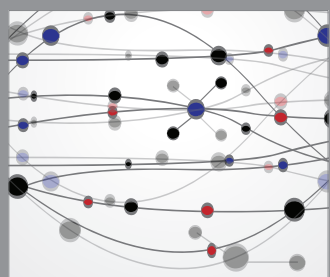

The Scientific World Journal
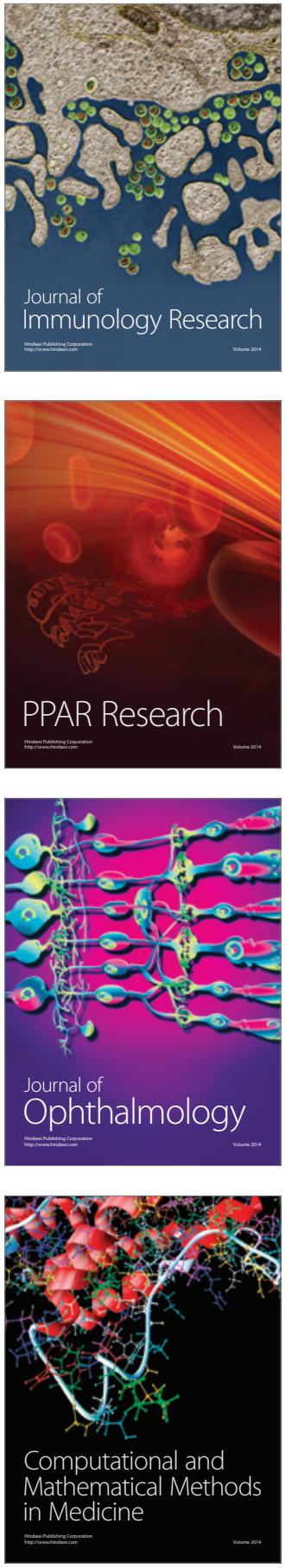

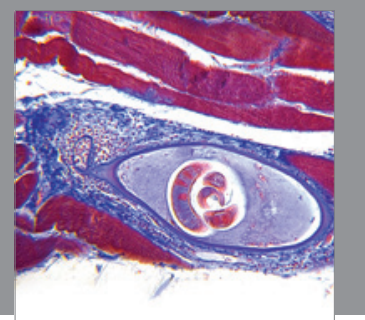

Gastroenterology

Research and Practice
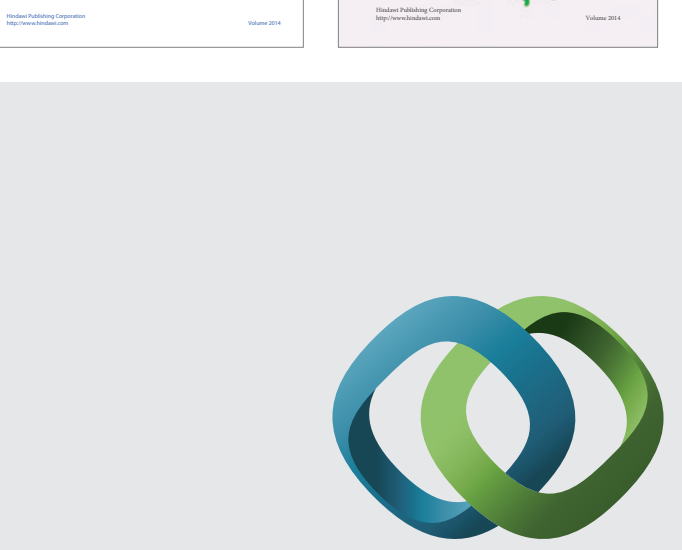

\section{Hindawi}

Submit your manuscripts at

http://www.hindawi.com
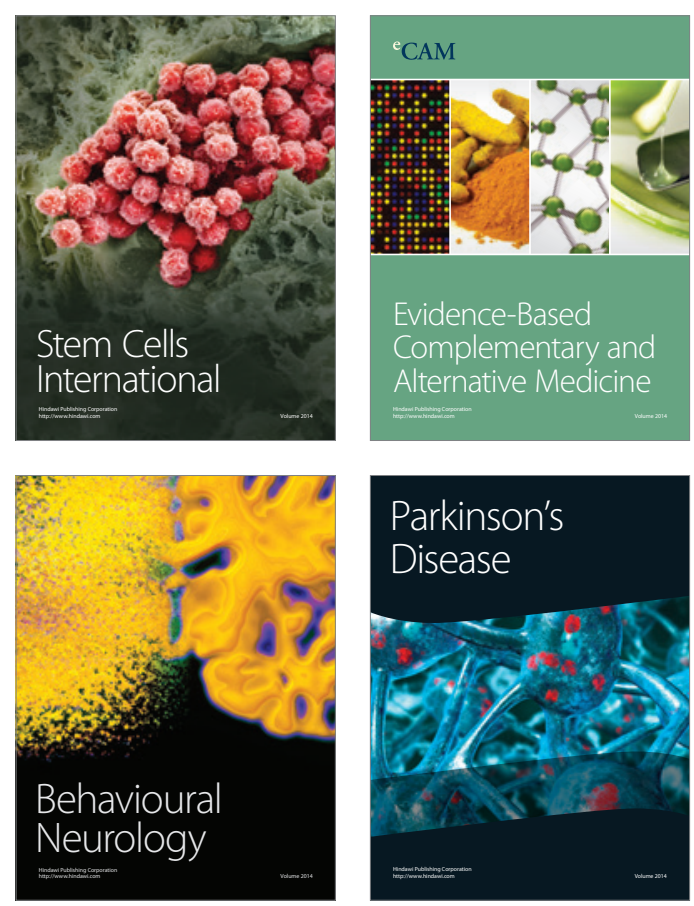

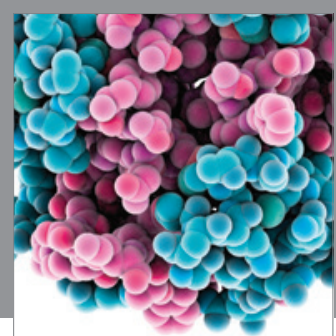

Journal of
Diabetes Research

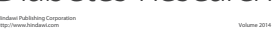

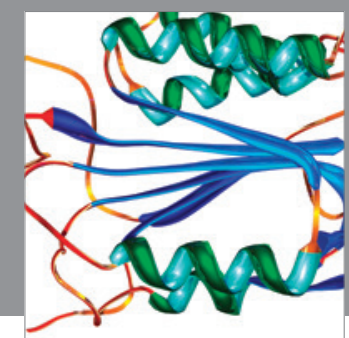

Disease Markers
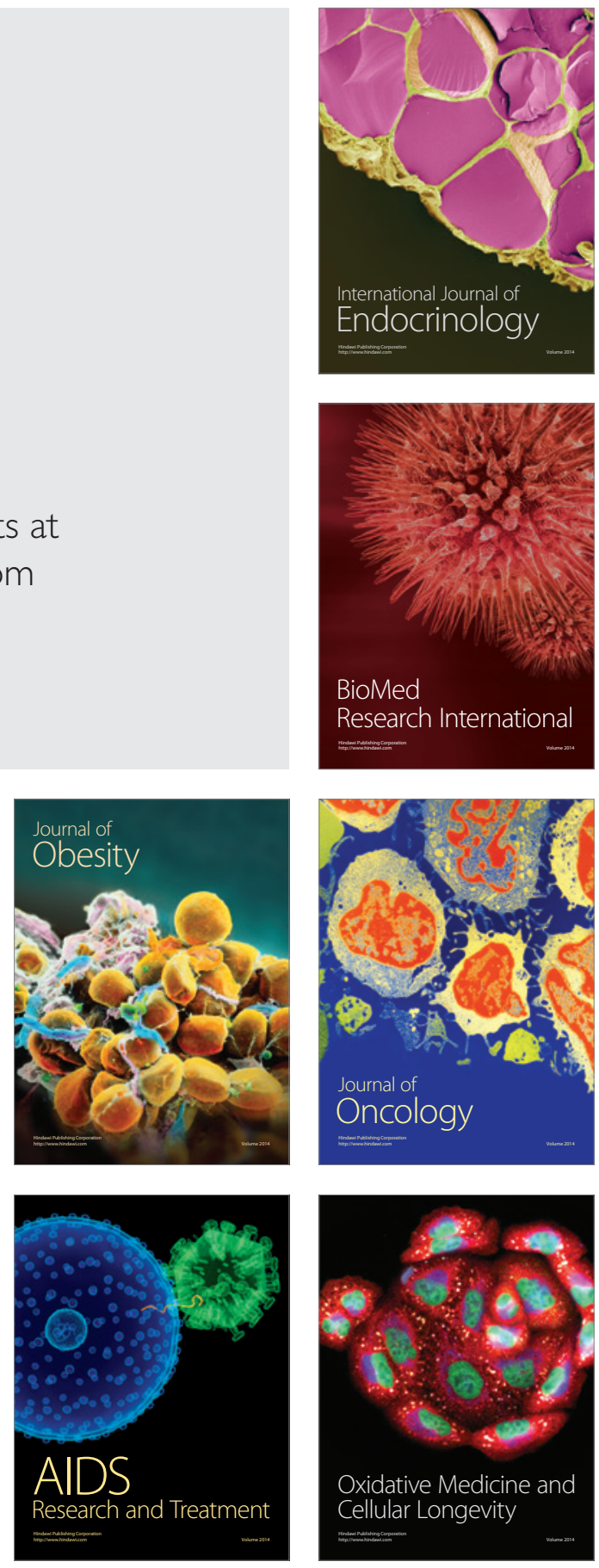